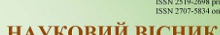

Centific messenger of Lviv National Univer

Lisowion

(11

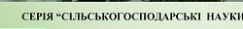

Том 23 № 95

2021
Науковий вісник Яьвівського національного університету ветеринарної медицини та біотехнодогій імені С.3. Гжицького. Серія: Сільськогосподарські науки

\author{
Scientific Messenger of Lviv National University
} of Veterinary Medicine and Biotechnologies. Series: Agricultural sciences

UDC 636.4.082:43

\title{
Signs of long-term adaptation and their relationship with the indicators of reproductive qualities in sows of the universal direction of productivity
}

\author{
V. I. Khalak ${ }^{1}$, B. V. Gutyj ${ }^{2}$, S. O. Usenko ${ }^{3}$, A. M. Shostya ${ }^{3}$ \\ ${ }^{1}$ State Institution Institute of Grain Crops NAAS of Ukraine, Dnipro, Ukraine \\ ${ }^{2}$ Stepan Gzhytskyi National University of Veterinary Medicin and Biotechnologies, Lviv, Ukraine \\ ${ }^{3}$ Poltava State Agrarian Academy, Poltava, Ukraine
}

\section{Article info}

Received 01.07.2021

Received in revised form 02.08 .2021

Accepted 03.08.2021

State Institution Institute of grain crops of NAAS, V. Vernadsky Str., 14, Dnipro, 49027, Ukraine.

Tel.: +38-067-892-44-04 E-mail:v16kh91@gmail.com

Stepan Gzhytskyi National University of Veterinary Medicine and Biotechnologies Lviv, Pekarska Str., 50, Lviv, 79010, Ukraine. Tel.: +38-068-136-20-54 E-mail:bvh@ukr.net

Poltava State Agrarian Academy, Skovorody Str., 1/3, Poltava, 36003, Ukraine.

Tel. +38-050-521-15-60

E-mail: sveta_usenko@ukr.net
Khalak, V. I., Gutyj, B. V., Usenko, S. O., \& Shostya, A. M. (2021). Signs of long-term adaptation and their relationship with the indicators of reproductive qualities in sows of the universal direction of productivity. Scientific Messenger of Lviv National University of Veterinary Medicine and Biotechnologies. Series: Agricultural sciences, 23(95), 147-153. doi: 10.32718/nvlvet-a9522

The paper presents the results of the study of signs of long-term adaptation and indicators of reproductive qualities of sows of the universal direction of productivity, as well as calculates the economic efficiency of research results. The experimental part of the work was performed in the agricultural formations of the Dnipropetrovsk region and the laboratory of animal husbandry of the State Institution "Institute of Grain Crops of NAAS of Ukraine". The work was performed in accordance with the research program № 31 "Genetic improvement of farm animals, their reproduction and conservation of biodiversity (Genetics, conservation, and reproduction of bioresources in animal husbandry)", task-31.02.01.18. pigs of different genotypes and to develop an integrated system for creating a highly productive population" (№ DR 0121U107903). Evaluation of sows on the indicators of long-term adaptation and reproductive qualities was carried out taking into account the following characteristics: life expectancy, months; duration of breeding use, months; farrowing was obtained; received piglets total, ch.; obtained live piglets, ch.; multiplicity, ch.; nest weight at the time of weaning at the age of 28 days, $\mathrm{kg}$; safety of piglets before weaning, \%. The index "level of adaptation" was calculated according to the method of Smirnov (2003), the index of reproductive qualities - according to the method of M. D. Berezovsky. Economic efficiency of research results and biometric processing of the obtained data were carried out according to generally accepted methods. It is established that sows of large white breeds of the controlled herd are characterized by rather high indicators of reproductive qualities and level of adaptation to conditions of intensive technology of operation. The life expectancy of sows in the main herd is 44.1 months, the duration of breeding use - 32.8 months, the index "level of adaptation" - 11.87 points. According to the indicators of fertility and nest weight at the time of weaning, the animals of the main herd belong to the first class and the elite class. Taking into account intra-breed differentiation according to the index "level of adaptation" sows of class $M^{-}$significantly outperformed peers of class $M^{+}$in life expectancy by $54.77 \%$, duration of breeding use - by $71.48 \%$, index "level of adaptation" - by $66.09 \%$. Significant differences between groups of animals of these classes were found by multiplicity $(t d=2.22 ; P<0.05)$, nest weight at the time of weaning at the age of 28 days, $\mathrm{kg}(\mathrm{td}=2.56 ; P<0.01)$ and index $M D$ Berezovsky $(t d=2.60 ; P<0.01)$. The coefficients of pair correlation between traits that characterize the level of adaptation and reproductive qualities of sows range from $-0.704(\mathrm{tr}=10.80)$ to $+0.982(\mathrm{tr}=213.05)$. The use of sow class $M$-according to the index "level of adaptation" provides an increase in additional products at the level of $+5.71 \%$, or $140.80 \mathrm{UAH}$. We propose to select repair young stock from sows of the leading group with the index "level of adaptation" of 6.55-8.08 points in the conditions of breeding plants and breeders, as well as industrial complexes.

Key words: sow, life expectancy, duration of breeding use, reproductive qualities, index, level of adaptation, economic efficiency, variability, correlation. 


\title{
Ознаки довготривалої адаптації та їх зв'язок 3 показниками відтворювальних якостей у свиноматок універсального напрямку продуктивності
}

\author{
В. І. Халак ${ }^{1}$, Б. В. Гутий ${ }^{2}$ С. О. Усенко ${ }^{3}$, А. М. Шостя ${ }^{3}$ \\ ${ }^{1}$ Держсавна установа Інститут зернових культур НААН Украӥни, м. Дніпро, Україна \\ ${ }^{2}$ Львівський національний університет ветеринарної медицини та біотехнологій імені С. 3. Гжицького, м. Львів, \\ Украӥна \\ ${ }^{3}$ Полтавська державна аграрна академія, м. Полтава, Україна
}

В роботі наведено результати дослідження ознак довготривалої адаптації та показників відтворювальних якостей свиноматок універсального напрямку продуктивності, а також розраховано економічну ефективність результатів досліджень. Експериментальну частину роботи виконано в агроформуваннях Дніпропетровської області та лабораторії тваринництва Державної установи “Інститут зернових культур НААН України”. Роботу виконано згідно з програмою наукових досліджень № 31 “Генетичне поліпшення сільськогосподарських тварин, їх відтворення та збереження біорозмаїття (Генетика, збереження та відтворення біоресурсів у тваринництві)”, завдання - 31.02.01.18.П “Визначити адаптаційні особливості $і$ характер успадкування полігенно-спадкових ознак свиней різних генотипів та розробити інтегровану систему створення високопродуктивної популяції” (№ ДР 0121U107903). Очінку свиноматок за показниками довготривалої адаптації $і$ відтворювальних якостей проводили з урахуванням таких ознак: тривалість життя, міс.; тривалість племінного використання, міс.; одержано опоросів; одержано поросят усього, гол.; одержано живих поросят, гол.; багатоплідність, гол.; маса гнізда на час відлучення у віці 28 діб, кг; збереженість поросят до відлучення, \%. Індекс “рівень адаптації” розраховували за методикою Смірнова (2003), індекс відтворювальних якостей - за методикою М. Д. Березовського. Економічну ефективність результатів досліджень та біометричну обробку одержаних даних проводили за загальноприйнятими методиками. Встановлено, цио свиноматки великої білої породи підконтрольного стада характеризуються достатньо високими показниками відтворювальних якостей та рівня адаптації до умов інтенсивної технологї експлуатації. Тривалість життя свиноматок основного стада становить 44,1 місяия, тривалість племінного використання - 32,8 місяця, індекс “рівень адаптації” - 11,87 бала. За показниками багатоплідності та маси гнізда на час відлучення тварини основного стада належать до I класу та класу еліта. 3 урахуванням внутріпородної диференціації за індексом “рівень адаптації” свиноматки класу $M^{-}$достовірно переважали ровесниць класу $M^{+}$за тривалістю життя на 54,77 \%, тривалістю племінного використання - на 71,48\%, індексом “рівень адаптації” - на 66,09 \%. Достовірну різницю між групами тварин зазначених класів встановлено за багатоплідністю (td = 2,22; $P<0,05)$, масою гнізда на час відлучення у віці 28 діб, кг $(t d=2,56 ; P<0,01)$ та індексом М. Д. Березовського (td = 2,60; $P<0,01)$. Коефіцієнти парної кореляції між ознаками, щцо характеризують рівень адаптаџіï та відтворювальні якості свиноматок, коливаються у межах від -0,704 (tr $=10,80)$ до $+0,982$ $\left(\right.$ tr = 213,05). Використання свиноматки класу $M^{-}$за індексом “рівень адаптації” забезпечує одержання прибавки додаткової продукиї на рівні $+5,71 \%$, або 140,80 грн. Пропонуємо в умовах племінних заводів та репродукторів, а також промислових комплексів відбір ремонтного молодняку проводити від свиноматок провідної групи з індексом “рівень адаптацї” 6,55-8,08 бала.

Ключові слова: свиноматка, тривалість життя, тривалість племінного використання, відтворювальні якості, індекс, рівень адаптації, економічна ефективність, мінливість, кореляція.

\section{Вступ}

3 метою прискорення селекційного процесу, метою якого $є$ поліпшення ознак відтворювальних якостей свиноматок і кнурів-плідників, а також відгодівельних і м'ясних якостей їхнього потомства необхідно радикально вирішити питання щодо реконструкції виробничих приміщень та зміни технологічного обладнання, створення оптимальних умов утримання та годівлі тварин різних статево-вікових груп, впровадження інноваційних методів оцінки племінної цінності з використанням ДНК-маркерів та інше (Topikha \& Konovalov, 2009; Tolokoncev, 2010; Shulha et al., 2011; Vashchenko, 2011; Kovalenko, 2011; Vashchenko et al., 2015; Khalak, 2020).

Актуальними питаннями в роботі 3 популяцією свиней тієї чи іншої породи є об'єктивна оцінка рівня адаптації тварин до умов навколишнього середовища, а також показників їхньої продуктивності (Hohlov et al., 2011; Kislinskaja et al., 2012; Kozyr et al., 2019; Khalak et al., 2021).

Мета роботи - дослідити ознаки довготривалої адаптації та показники відтворювальних якостей свиноматок універсального напрямку продуктивності, а також розрахувати економічну ефективність результатів досліджень.

\section{Матеріал і методи досліджень}

Експериментальну частину досліджень проведено в агроформуваннях Дніпропетровської області та лабораторії тваринництва Державної установи “Інститут зернових культур НААН України”. Роботу виконано згідно 3 програмою наукових досліджень № 31 "Генетичне поліпшення сільськогосподарських тварин, їх відтворення та збереження біорозмаїття (Генетика, збереження та відтворення біоресурсів у тваринництві)", завдання - 31.02.01.18.П "Визначити адаптаційні особливості і характер успадкування полігенно-спадкових ознак свиней різних генотипів та розробити інтегровану систему створення високопродуктивної популяції” (№ ДР 0121U107903).

Оцінку свиноматок великої білої породи за ознаками довготривалої адаптації та відтворювальних якостей проводили з урахуванням таких показників: тривалість життя, міс.; тривалість племінного використання, міс.; індекс “рівень адаптації”, бала, одержано опоросів, одержано поросят усього, гол.; одержано живих поросят, гол.; багатоплідність, голю; маса гніз- 
да на час відлучення у віці 28 діб, кг; збереженість поросят до відлучення, \%.

Індекс “рівень адаптації” (1), індекс М. Д. Березовського (2) та вартість додаткової продукції (3) розраховували за такими формулами:

$$
\text { PA }=\frac{\text { ТЖ }{ }^{2}}{\text { кількість опоросів } \times \text { ТПВ ( міс ) }},
$$

де: РА - індекс “рівень адаптації, бала; ТЖ - тривалість життя свиноматки (від народження до останнього відлучення поросят), міс.; ТПВ - тривалість племінного використання (від початку першої поросності до останнього відлучення поросят), міс. (Smirnov, 2003);

$$
I=B+2 W+35 G \text {, }
$$

де: $\mathrm{B}$ - кількість поросят при народженні, гол.; W - кількість відлучених поросят, гол.; G - середньодобовий приріст до відлучення, кг (Vashchenko, 2019);

$$
E=Ц \times \frac{C \times \Pi}{100} \times \pi \times K,
$$

де: Е - вартість додаткової продукції, грн.; Ц - закупівельна ціна одиниці продукції відповідно до цін, які діють в Україні; C - середня продуктивність тварин; П -середня надбавка основної продукції (\%), яка виражена у відсотках на 1 голову при застосуванні нового і поліпшеного селекційного досягнення порівняно $з$ продуктивністю тварин базового використання; Л - постійний коефіцієнт зменшення результату, який пов'язаний з додатковими витратами на прибуткову продукцію $(0,75)$; К - чисельність поголів'я сільськогосподарських тварин нового або поліпшеного селекційного досягнення, голів (Metodika opredelenija..., 1983).

Силу кореляційних зв'язків між ознаками визначали шкалою Чеддока (Sidorova, 2003) (табл. 1).

Біометричну обробку одержаних даних (Lakin, 1990) проводили за загальноприйнятими методиками.

\section{Таблиця 1}

Шкала Чеддока для градації сили кореляційного зв'язку

\begin{tabular}{cc}
\hline $\begin{array}{c}\text { Значення коефіцієнта } \\
\text { кореляції }\end{array}$ & $\begin{array}{c}\text { Сила кореляційного } \\
\text { зв'язку }\end{array}$ \\
\hline $0,1-0,3$ & Слабка \\
$0,3-0,5$ & Помірна \\
$0,5-0,7$ & Помітна \\
$0,7-0,9$ & Висока \\
$0,9-0,99$ & Дуже висока \\
\hline
\end{tabular}

\section{Результати та їх обговорення}

Встановлено, що тривалість життя свиноматок основного стада становить 44,1 $\pm 1,97$ місяця, тривалість племінного використання - 32,8 $\pm 1,95$ місяця, індекс “рівень адаптації” - 11,87 \pm 0,709 бала. За період племінного використання від свиноматок підконтрольної популяції одержано $6,1 \pm 0,36$ опоросів, поросят усього $-65,8 \pm 4,41$ гол., живих поросят $-62,5 \pm 4,17$ гол. Їхня багатоплідність становить $10,2 \pm 0,20$ поросят на один опорос, маса гнізда на час відлучення у віці 28 діб - 77,0 \pm 1,02 кг, збереженість поросят до відлучення - 95,0 \%, тривалість міжопоросного періоду $175,5 \pm 3,92$ діб, кількість непродуктивних діб з розрахунку на один опорос $-27,0 \pm 2,87$.

Кількість свиноматок, від яких одержано за період племінного використання 100 і більше живих поросят, дорівнює $29,72 \%$.

Співвідношення тривалості племінного використання до тривалості життя у свиноматок підконтрольної популяції становить 74,37 \%.

Коефіцієнт варіації ознак довготривалої адаптації та показників відтворювальних якостей свиноматок великої білої породи коливається у межах від 10,28 до $53,41 \%$ (табл. 2).

\section{Таблиця 2}

Показники мінливості ознаки довготривалої адаптації та показників відтворювальних якостей свиноматок великої білої породи, $\mathrm{n}=60$

\begin{tabular}{lrc}
\hline \multicolumn{1}{c}{ Показники, одиниці виміру } & \multicolumn{2}{c}{ Показники мінливості } \\
\cline { 2 - 3 } & \multicolumn{1}{c}{$\sigma \pm \mathrm{S}_{\sigma}$} & $35,94 \pm 3,282$ \\
Тривалість життя, міс. & $15,85 \pm 1,447$ & $47,59 \pm 4,346$ \\
Тривалість племінного використання, міс. & $15,61 \pm 1,425$ & $47,85 \pm 4,369$ \\
Індекс “рівень адаптаціі”, бала & $5,68 \pm 0,518$ & $47,86 \pm 4,370$ \\
Одержано опоросів & $2,92 \pm 0,267$ & $53,41 \pm 4,877$ \\
Одержано поросят усього, гол. & $35,15 \pm 3,027$ & $53,28 \pm 4,865$ \\
Одержано живих поросят, гол. & $33,30 \pm 3,041$ & $15,49 \pm 1,414$ \\
Багатоплідність, гол. & $1,58 \pm 0,001$ & $10,28 \pm 0,938$ \\
Маса гнізда на час відлучення у віці 28 діб, кг & $7,92 \pm 0,723$ & \\
\hline
\end{tabular}

Результати дослідження зазначених ознак у свиноматок різних класів розподілу за індексом “рівень адаптації” наведено у таблиці 3.

Встановлено, що свиноматки класу $\mathrm{M}^{-}$за показником “тривалість життя, міс.” переважали ровесниць класу $\mathrm{M}^{+}$на 32,1 міс. ( $\left.\mathrm{td}=10,15 ; \mathrm{P}<0,001\right)$, “трива- лість племінного використання, міс.” - 35,1 міс. (td = 13,65; Р < 0,001), “одержано опоросів" - 7,1 (td = $15,43 ; \mathrm{P}<0,001)$. Різниця між групами за індексом “рівень адаптаціiі” становить 14,27 бала $(\mathrm{td}=6,39 ; \mathrm{P}<$ 0,001). 
Таблиця 3

Тривалість життя, племінного використання і відтворювальні якості свиноматок різних класів розподілу за індексом “рівень адаптаціі”

\begin{tabular}{|c|c|c|c|c|}
\hline \multirow{4}{*}{ Показники, одиниці виміру } & \multirow{4}{*}{$\begin{array}{c}\text { Біометричні } \\
\text { показники }\end{array}$} & \multicolumn{3}{|c|}{ Індекс “рівень адаптаціï”, балів } \\
\hline & & $16,61-39,62$ & $8,48-15,41$ & $6,55-8,08$ \\
\hline & & \multicolumn{3}{|c|}{ клас розподілу } \\
\hline & & $\mathrm{M}^{+}$ & $\mathrm{M}^{0}$ & $\mathrm{M}^{-}$ \\
\hline \multirow{4}{*}{ Тривалість життя, міс. } & $\mathrm{n}$ & 11 & 34 & 15 \\
\hline & $\overline{\mathrm{X}} \pm S \bar{x}$ & $26,5 \pm 2,32$ & $42,2 \pm 2,45$ & $58,6 \pm 2,16^{* * *}$ \\
\hline & $\sigma \pm \mathrm{S}_{\sigma}$ & $7,33 \pm 1,639$ & $14,30 \pm 1,735$ & $8,38 \pm 1,531$ \\
\hline & $\mathrm{C}_{\mathrm{v}} \pm \mathrm{S}_{\mathrm{Cv}}, \%$ & $27,60 \pm 6,174$ & $33,88 \pm 4,111$ & $14,30 \pm 2,614$ \\
\hline \multirow{2}{*}{$\begin{array}{l}\text { Тривалість племінного використання, } \\
\text { міс. }\end{array}$} & $\overline{\mathrm{x}} \pm S \bar{x}$ & $14,0 \pm 1,39$ & $30,5 \pm 2,16$ & $49,1 \pm 2,17 * * *$ \\
\hline & $\sigma \pm \mathrm{S}_{\sigma}$ & $4,40 \pm 0,984$ & $12,64 \pm 1,533$ & $8,41 \pm 1,537$ \\
\hline Співвідношення: тривалість & $\mathrm{C}_{\mathrm{v}} \pm \mathrm{S}_{\mathrm{Cv}}, \%$ & $31,42 \pm 7,123$ & $41,44 \pm 5,029$ & $17,12 \pm 3,129$ \\
\hline $\begin{array}{l}\text { племінного використання: } \\
\text { тривалість життя, \% }\end{array}$ & - & 52,83 & 72,27 & 83,78 \\
\hline \multirow{3}{*}{ Одержано опоросів } & $\overline{\mathrm{X}} \pm S \bar{x}$ & $2,5 \pm 0,30$ & $5,4 \pm 0,34$ & $9,6 \pm 0,36^{* * *}$ \\
\hline & $\sigma \pm \mathrm{S}_{\sigma}$ & $0,97 \pm 0,217$ & $2,00 \pm 0,242$ & $1,40 \pm 0,255$ \\
\hline & $\mathrm{C}_{\mathrm{v}} \pm \mathrm{S}_{\mathrm{Cv}}, \%$ & $38,87 \pm 8,695$ & $37,03 \pm 4,493$ & $14,58 \pm 2,665$ \\
\hline \multirow{3}{*}{ Індекс “рівень адаптації”, балів } & $\overline{\mathrm{X}} \pm S \bar{x}$ & $21,59 \pm 2,236$ & $11,16 \pm 0,364$ & $7,32 \pm 0,118^{* * *}$ \\
\hline & $\sigma \pm \mathrm{S}_{\sigma}$ & $7,07 \pm 1,581$ & $2,12 \pm 0,257$ & $0,45 \pm 0,082$ \\
\hline & $\mathrm{C}_{\mathrm{v}} \pm \mathrm{S}_{\mathrm{Cv}}, \%$ & $32,74 \pm 7,324$ & $18,99 \pm 2,304$ & $6,14 \pm 1,122$ \\
\hline \multirow{3}{*}{ Одержано поросят усього, гол. } & $\overline{\mathrm{X}} \pm S \bar{x}$ & $23,6 \pm 3,78$ & $58,0 \pm 4,19$ & $106,2 \pm 5,48 * * *$ \\
\hline & $\sigma \pm \mathrm{S}_{\sigma}$ & $11,98 \pm 2,680$ & $24,47 \pm 2,969$ & $21,25 \pm 3,884$ \\
\hline & $\mathrm{C}_{\mathrm{v}} \pm \mathrm{S}_{\mathrm{Cv}}, \%$ & $50,76 \pm 11,355$ & $42,18 \pm 5,118$ & $20,00 \pm 3,65$ \\
\hline \multirow{3}{*}{ Одержано живих поросят, гол. } & $\overline{\mathrm{X}} \pm S \bar{x}$ & $21,4 \pm 3,60$ & $55,7 \pm 3,96$ & $100,8 \pm 4,91 * * *$ \\
\hline & $\sigma \pm \mathrm{S}_{\sigma}$ & $11,38 \pm 2,545$ & $23,13 \pm 2,807$ & $19,02 \pm 3,477$ \\
\hline & $\mathrm{C}_{\mathrm{v}} \pm \mathrm{S}_{\mathrm{Cv}}, \%$ & $53,17 \pm 11,894$ & $41,52 \pm 5,038$ & $18,86 \pm 3,44$ \\
\hline \multirow{3}{*}{ Багатоплідність, гол. } & $\overline{\mathrm{X}} \pm S \bar{x}$ & $8,5 \pm 0,88$ & $10,3 \pm 0,17$ & $10,5 \pm 0,25^{*}$ \\
\hline & $\sigma \pm \mathrm{S}_{\sigma}$ & $2,79 \pm 0,624$ & $1,02 \pm 0,123$ & $0,97 \pm 0,177$ \\
\hline & $\mathrm{C}_{\mathrm{v}} \pm \mathrm{S}_{\mathrm{Cv}}, \%$ & $32,82 \pm 7,342$ & $9,99 \pm 1,212$ & $9,23 \pm 1,687$ \\
\hline $\begin{array}{l}\text { Кількість свиноматок класу еліта за } \\
\text { багатоплідністю, \% }\end{array}$ & 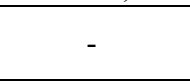 & 10,0 & 17,64 & 33,33 \\
\hline \multirow{3}{*}{$\begin{array}{l}\text { Маса гнізда на час відлучення у віці } \\
28 \text { діб, кг }\end{array}$} & $\overline{\mathrm{X}} \pm S \bar{x}$ & $75,5 \pm 1,90$ & $76,7 \pm 1,52$ & $81,4 \pm 1,37 * *$ \\
\hline & $\sigma \pm \mathrm{S}_{\sigma}$ & $6,02 \pm 1,346$ & $8,90 \pm 1,080$ & $5,34 \pm 0,976$ \\
\hline & $\mathrm{C}_{\mathrm{v}} \pm \mathrm{S}_{\mathrm{Cv}}, \%$ & $7,97 \pm 1,782$ & $11,60 \pm 1,407$ & $6,56 \pm 1,199$ \\
\hline $\begin{array}{l}\text { Збереженість поросят до відлучення, } \\
\text { \% }\end{array}$ & $\overline{\mathrm{X}} \pm S \bar{x}$ & $95,5 \pm 1,84$ & $92,2 \pm 0,94$ & $94,3 \pm 1,79$ \\
\hline \multirow{3}{*}{ Індекс М. Д. Березовського, бала } & $\overline{\mathrm{X}} \pm S \bar{x}$ & $34,53 \pm 1,410$ & $36,89 \pm 0,368$ & $38,43 \pm 0,586^{* *}$ \\
\hline & $\sigma \pm \mathrm{S}_{\sigma}$ & $4,46 \pm 0,997$ & $2,14 \pm 0,259$ & $2,27 \pm 0,414$ \\
\hline & $\mathrm{C}_{\mathrm{v}} \pm \mathrm{S}_{\mathrm{Cv}}, \%$ & $12,91 \pm 2,888$ & $5,80 \pm 0,703$ & $5,90 \pm 1,078$ \\
\hline
\end{tabular}

Примітка: $*-\mathrm{P}<0,05 ; * *-\mathrm{P}<0,01 ; * * *-\mathrm{P}<0,001$

Різниця між зазначеними групами піддослідних тварин за показником “одержано поросят усього, гол.” дорівнює 82,6 гол. (td = 12,42; $\mathrm{P}<0,001)$, “одержано живих поросят усього, гол.” - 79,4 гол. $(\mathrm{td}=13,05 ; \mathrm{P}<0,001)$, “багатоплідність, гол.” - 2,0 гол. (td. $=2,22 ; \mathrm{P}<0,05)$, “маса гнізда на час відлучення у віці 28 діб, кг” - 5,9 кг (td = 2,56; Р < 0,01), “індекс М. Д. Березовського" - 3,9 бала $(\mathrm{td}=2,60$; $\mathrm{P}<0,01)$.

Коефіцієнт мінливості ознак, що характеризує рівень адаптації та відтворювальні якості свиноматок піддослідних груп, коливається у межах від 6,560 (клас розподілу свиноматок за індексом “рівень адап- тації” - $\mathrm{M}^{-}$, показник - маса гнізда на час відлучення у віці 28 діб) до 53,17 \% (клас розподілу свиноматок за індексом “рівень адаптаціӥ” - $\mathrm{M}^{+}$, показник - одержано живих поросят, гол.).

Результати розрахунків коефіцієнта парної кореляції між ознаками, що характеризують рівень адаптації свиней, та показниками відтворювальних якостей наведено в таблиці 4.

Коефіцієнт парної кореляції між ознаками, що характеризують рівень адаптації свиней, та показниками відтворювальних якостей коливається у межах від $0,704(\operatorname{tr}=10,80)$ до $+0,982(\operatorname{tr}=213,05)$. 
Таблиця 4

Коефіцієнти парної кореляції між ознаками, що характеризують рівень адаптації свиноматок та їх відтворювальні якості

\begin{tabular}{|c|c|c|c|c|}
\hline \multicolumn{2}{|l|}{ Показник (ознака) } & \multicolumn{2}{|c|}{ Біометричні показники } & \multirow{2}{*}{$\begin{array}{c}\text { Сила кореляційного } \\
\text { 3в'язку }\end{array}$} \\
\hline$x$ & $y$ & $\mathrm{r} \pm \mathrm{Sr}$ & $\operatorname{tr}$ & \\
\hline \multirow{7}{*}{ Тривалість життя, міс. } & 1 & $0,951 \pm 0,0124 * * *$ & 7,70 & Дуже висока \\
\hline & 2 & $0,939 \pm 0,0153 * * *$ & 61,45 & Дуже висока \\
\hline & 3 & $0,940 \pm 0,0150 * * *$ & 62,51 & Дуже висока \\
\hline & 4 & $0,415 \pm 0,1069 * * *$ & 3,88 & Помірна \\
\hline & 5 & $0,197 \pm 0,1242$ & 1,59 & Слабка \\
\hline & 6 & $-0,147 \pm 0,1264$ & 1,16 & Слабка \\
\hline & 7 & $0,409 \pm 0,1076^{* * *}$ & 3,80 & Помірна \\
\hline \multirow{7}{*}{$\begin{array}{c}\text { Тривалість племінного використання, } \\
\text { міс. }\end{array}$} & 1 & $0,969 \pm 0,0079 * * *$ & 122,87 & Дуже висока \\
\hline & 2 & $0,980 \pm 0,0510 * * *$ & 191,55 & Дуже висока \\
\hline & 3 & $0,982 \pm 0,0046 * * *$ & 213,05 & Дуже висока \\
\hline & 4 & $0,405 \pm 0,1080 * * *$ & 3,75 & Помірна \\
\hline & 5 & $0,214 \pm 0,1233$ & 1,74 & Слабка \\
\hline & 6 & $-0,123 \pm 0,1272$ & 0,97 & Слабка \\
\hline & 7 & $0,415 \pm 0,1069 * * *$ & 3,88 & Помірна \\
\hline \multirow{7}{*}{ Індекс “рівень адаптації”, балів } & 1 & $-0,704 \pm 0,0652 * * *$ & 10,80 & Висока \\
\hline & 2 & $0,980 \pm 0,0051^{* * *}$ & 191,55 & Дуже висока \\
\hline & 3 & $0,982 \pm 0,0046 * * *$ & 213,05 & Дуже висока \\
\hline & 4 & $0,405 \pm 0,1080 * * *$ & 3,75 & Помірна \\
\hline & 5 & $0,214 \pm 0,1233$ & 1,74 & Слабка \\
\hline & 6 & $-0,123 \pm 0,1272$ & 0,977 & Слабка \\
\hline & 7 & $0,415 \pm 0,1069 * * *$ & 3,88 & Помірна \\
\hline
\end{tabular}

Примітка: 1 - одержано опоросів; 2 - одержано поросят усього, гол.; 3 - одержано живих поросят, гол.; 4 - багатоплідність, гол.; 5 - маса гнізда на час відлучення у віці 28 діб, кг; 6 - збереженість, \%; 7 - індекс М. Д. Березовського, бала; *** - Р < 0,001

Достовірні коефіцієнти кореляції встановлено за такими парами ознак: тривалість життя $\times$ одержано опоросів $(\mathrm{r}=0,951)$, тривалість життя $\times$ одержано поросят усього $(\mathrm{r}=0,939)$, тривалість життя $\times$ одержано живих поросят $(\mathrm{r}=0,940)$, тривалість життя $\times$ багатоплідність $(\mathrm{r}=0,415)$, тривалість життя $\times$ індекс М. Д. Березовського) $(\mathrm{r}=0,409)$, тривалість племінного використання $\times$ одержано опоросів $(\mathrm{r}=0,969)$, тривалість племінного використання $\times$ одержано поросят усього $(\mathrm{r}=0,980)$, тривалість племінного використання $\times$ одержано живих поросят $(\mathrm{r}=0,982)$, тривалість племінного використання $\times$ багатоплідність $(\mathrm{r}=0,405)$, індекс “рівень адаптації” $\times$ одержано опоросів $(\mathrm{r}=-0,704)$, індекс “рівень адаптаціі” $\times$ одержано поросят усього $(\mathrm{r}=0,980)$, індекс “рівень адаптаціï” $\times$ одержано живих поросят $(\mathrm{r}=0,982)$, індекс “рівень адаптаціï” × багатоплідність $(\mathrm{r}=0,405)$, індекс “рівень адаптації” $\times$ індекс М. Д. Березовського $(\mathrm{r}=0,415)$.

Розрахунок економічної ефективності використання свиноматок великої білої породи різного рівня адаптації свідчить, що максимальну прибавку продукції одержано від тварин класу $\mathrm{M}^{-}$(+5,71 \%) (табл. 5).

Таблиця 5

Економічна ефективність використання свиноматок різних класів розподілу за індексом “рівень адаптаціі”

\begin{tabular}{ccccc}
\hline $\begin{array}{c}\text { Клас розподілу за індексом } \\
\text { "рівень адаптації” }\end{array}$ & $\mathrm{n}$ & $\begin{array}{c}\text { Маса гнізда на дату від- } \\
\text { лучення у віці } 28 \text { діб, кг }\end{array}$ & $\begin{array}{c}\text { Прибавка додаткової } \\
\text { продукції, \% }\end{array}$ & $\begin{array}{c}\text { Вартість додаткової про- } \\
\text { дукції, грн/гол./опорос }\end{array}$ \\
\hline Загальна вибірка & 60 & $77,0 \pm 1,02$ & - & - \\
$\mathrm{M}^{+}$ & 10 & $75,5 \pm 1,90$ & $-1,94$ & $-47,83$ \\
$\mathrm{M}^{0}$ & 34 & $76,7 \pm 1,52$ & $-0,38$ & $-9,37$ \\
$\mathrm{M}^{-}$ & 15 & $81,4 \pm 1,37$ & $+5,71$ & $+140,80$ \\
\hline
\end{tabular}

Примітка: ціна реалізації молодняку на переробні підприємства Дніпропетровської області на час проведення експериментальної частини досліджень дорівнювала 42,7 грн за 1 кг живої маси

Вартість додаткової продукції, яку одержують від однієї свиноматки зазначеної групи, становить $+140,80$ грн.

\section{Висновки}

1. Встановлено, що свиноматки великої білої породи підконтрольного стада характеризуються достатньо високими показниками відтворювальних якостей та рівня адаптації до умов інтенсивної технології експлуатації. Тривалість життя свиноматок основного стада становить 44,1 місяця, тривалість племінного використання - 32,8 місяця, індекс “рівень адаптації" - 11,87 бала. За показниками багатоплідності та маси гнізда на час відлучення тварини основного стада належать до I класу та класу еліта.

2. 3 урахуванням внутріпородної диференціації за індексом "рівень адаптації" свиноматки класу $\mathrm{M}^{-}$ 
достовірно переважали ровесниць класу $\mathrm{M}^{+}$за тривалістю життя на 54,77 \%, тривалістю племінного використання - на 71,48 \%, індексом “рівень адаптації" на 66,09 \%. Достовірну різницю між групами тварин зазначених класів встановлено за багатоплідністю $(\mathrm{td}=2,22 ; \mathrm{P}<0,05)$, масою гнізда на час відлучення у віці 28 діб, кг $(\mathrm{td}=2,56 ; \mathrm{P}<0,01)$ та індексом М. Д. Березовського $(\mathrm{td}=2,60 ; \mathrm{P}<0,01)$.

3. Коефіцієнти парної кореляції між ознаками, що характеризують рівень адаптації та відтворювальні якості свиноматок, коливаються у межах від $-0,704$ $(\operatorname{tr}=10,80)$ до $+0,982(\operatorname{tr}=213,05)$.

4. Використання свиноматки класу $\mathrm{M}^{-}$за індексом індекс “рівень адаптаціі” забезпечує одержання прибавки додаткової продукції на рівні $+5,71 \%$, або 140,80 грн.

5. Пропонуємо в умовах племінних заводів та репродукторів, а також промислових комплексів відбір ремонтного молодняку проводити від свиноматок провідної групи 3 індексом “рівень адаптації” 6,558,08 бала.

\section{References}

Berezovskyi, M. D. (2014). Problemni pytannia z udoskonalennia pleminnoho svynarstva $\mathrm{v}$ Ukraini ta yikh vyrishennia. Svynarstvo: mizhvidomch. temat. nauk. zb. In-tu svynarstva i APV NAAN, 64, 37-48 (in Ukrainian).

Halak, V. I. (2020). Jekspluatacionnaja cennost' svinomatok krupnoj beloj porody i jekonomicheskaja jeffektivnost' ih ispol'zovanija. Aktual'nye napravlenija innovacionnogo razvitija zhivotnovodstva i sovremennyh tehnologij produktov pitanija: materialy Mezhdunar. nauch.-prakt. konf. (pos. Persianovskij, Donskoj GAU 27 nojabrja 2020 g.), 24-29 (in Russian).

Hohlov, A. M., Baranovskij, D. I., \& Gerasimov, V. I. (2011). Nekotorye osobennosti adaptacii orga-nizma svinej pri gibridizacii. Tavrijs'kij naukovij visnik. Herson, 76(2), 91-96 (in Russian).

Khalak, V. I. (2020). Novi metody intehrovanoi otsinky svynomatok za pokaznykamy vidtvoriuvalnykh yakostei. Zernovi kultury, 4(2), 396-403. doi: 10.31867/2523-4544/0149 (in Ukrainian).

Khalak, V., Gutyj, B., Stadnytska, O., Shuvar, I., Balkovskyi, V., Korpita, H., Shuvar, A., Bordun, O. (2021). Breeding value and productivity of sows of the Large White breed. Ukrainian Journal of Ecology, 11(1), 319-324. doi: 10.15421/2021 48.

Khalak, V. I., Gutyj, B. V., Bordun, O. M., Stadnytska, O. I., \& Chernyavsky, S. E. (2021). Level of phenotypic consolidation and correlation analysis of reproductive qualities of sows of different breeding value. Scientific Messenger of Lviv National University of Veterinary Medicine and Biotechnologies. Series: Agricultural sciences, 23(94), 117-122. doi: 10.32718/nvlvet-a9421.

Khalak, V. I., Gutyj, B. V., Il'chenko, M. O., \& Smyslov, S. U. (2021). Variability and associative relationship of some biochemical indicators of blood serum and physical-chemical properties of Large White breed stores' muscle tissue. Bulletin of Poltava State Agrarian Academy, 2, 152-157. doi: 10.31210/visnyk2021.02.18.
Khalak, V., Dudchak, I., Gutyj, B., Stadnytska, O., Vakulik, V., Pundiak, T., Zmiia, M., Slepokura, O., Bordun, O., Smyslov, S. (2021). Some biochemical indicators of serum, fattening, and meat quality of young pigs of different classes of distribution according to the SazerFredin index. Ukrainian Journal of Ecology, 11(7), 6-13. doi: 10.15421/2021 236.

Khalak, V., Gutyj, B., Bordun, O., Stadnytska, O., \& Ilchenko, M. (2021). The biochemical indicators of blood serum and their relationship with fattening and meat qualities of young swine of different inbreed differentiation according to the sazer-fredin index. Scientific Papers. Series D. Animal Science, LXIV(2), 70 75. URL: http://rep.btsau.edu.ua/bitstream/BNAU/ 7009/1/Meat_qualities.pdf.

Kislinskaja, A. I., Kalinichenko, G. I., Shakun, A. P., \& Tyshko, N. I. (2012). Ocenka estestvennoj rezistentnosti organizma svinej krupnoj beloj porody vengerskoj selekcii v period adaptacii. Sovremennye ten-dencii i tehnologicheskie innovacii $\mathrm{v}$ svinovodstve: materialy HIH Mezhdunar. nauch.-prakt. konf. Gorki: BGSHA, 78-83 (in Russian).

Kovalenko, T. S. (2011). Udoskonalennia otsinky produktyvnykh i pleminnykh yakostei svynei za selektsiinymy indeksamy : avtoref. dys. ... kand. s.-h. nauk: 06.02.01. Poltava (in Ukrainian).

Kozyr, V., Khalak, V., \& Povod, M. (2019). DNA-type results swine for MC4R-gene and its association with productivity. Scientific Papers Series Management, Economic Engineering in Agriculture and Rural Development, 19(2), 227-232. URL: http://managementjournal.usamv.ro/pdf/vol.19_2/Art2 9.pdf.

Lakin, G. F. (1990). Biometrija. Moskva: Vysshaja shkola (in Russian).

Metodika opredelenija jekonomicheskoj jeffektivnosti ispol'zovanija v sel'skom hozjajstve rezul'tatov nauchno-issledovatel'skih rabot, novoj tehnologi, izobretenij i racionalizatorskih predlo-zhenij (1983). Moskva: VAIIPI (in Russian).

Shulha, Yu. I., Topchii, L. I., \& Popov, V. M. (2011). Adaptatsiina zdatnist svynei ukrainskoi stepovoi biloi porody. Tavriiskyi naukovyi visnyk. Kherson, 76(2), 67-71 (in Ukrainian).

Sidorova, A. V. (2003). Praktikum po teorii statistiki: Uchebnoe posobie. Doneck: Doneckij nac. un-tet (in Russian).

Smirnov, V. S. (2003). Ocenka adaptacii svinomatok k intensivnomu vosproizvodstvu. Zootehnija, 7, 22-25 (in Russian).

Tolokoncev, A. (2010). Vosprozvoditel'nye i adaptacionnye kachestva svinej. Zhivotnovodstvo Rossii, 4, 33 (in Russian).

Topikha, V. S., \& Konovalov, I. V. (2009). Adaptatsiini osoblyvosti svynei riznykh porid $\mathrm{v}$ umovakh VAT Plem-zavod "Stepnoi” Zaporizkoi oblasti. Visnyk ahrarnoi nauky Prychornomoria. Mykolaiv: MDAU, 4(51), 203-207 (in Ukrainian).

Vashchenko, P. A. (2011). Pleminna tsinnist svynei. Svynarstvo: mizhvidomch. temat. nauk. zb. In-tu svynarstva i APV NAAN, 59, 28-32 (in Ukrainian). 
Vashchenko, P. A. (2019). Prohnozuvannia pleminnoi tsinnosti svynei na osnovi liniinykh modelei selektsiinykh indeksiv ta DNK-markeriv: avtoref. dys. ... d-ra s.-h. nauk: 06.02.01. Mykolaiv (in Ukrainian).
Vashchenko, P. A., Berezovskyi, M. D., \& Nebylytsia, M. S. (2015). Vyznachennia pleminnoi tsinnosti svynei za vykorystannia liniinykh modelei: Metodychni rekomendatsii. Poltava: Instytut svynarstva i ahropromyslovoho vyrobnytstva NAAN (in Ukrainian). 